\title{
Photonics West 2017
}

\author{
Excitement over positive industry forecasts, high attendance and a quality programme was dampened \\ by travel restrictions to the United States.
}

Over the past few years SPIE's Photonics West event has evolved into perhaps the biggest optics conference of the annual calendar. This year, from 27 January to 1 February, and despite on-going major construction, the Moscone Centre in San Francisco hosted a staggering 23,000 attendees. The number of companies exhibiting again topped the 1,300 mark, with about 1,380 companies showing their latest wares at the show, including $\sim 200$ new product launches.

As pointed out by the news and analysis website www.optics.org, the meeting coincided with encouraging financial reports from some big players in the industry. IPG Photonics - known in particular for highpower fibre lasers - reported a 2016 fourth quarter sales increase of $25 \%$ year-over-year, pushing their annual sales over US $\$ 1$ billion for the first time and the forecast for 2017 is apparently positive.

The fourth quarter numbers for Coherent were also eagerly expected and under scrutiny, following their recent US\$942 million acquisition of Rofin (a company also known for fibre lasers). Coherent announced improved profitability and 2016 fourth quarter sales of US\$346 million. In other good news, due to increased earnings overall, but particularly in their Optics and Life Science division, Jenoptik has eliminated its net debt.

Apart from the broad scientific programme, one of the most striking things was hearing US citizens apologize for the actions of their country, referring to the recent executive order banning entry into the United States for citizens from Iran, Iraq, Libya, Somalia, Sudan, Syria and Yemen. The travel ban has been referred to by some as a 'Muslim ban'.

"I made a statement of apology to the Muslim members of the audience regarding the way Muslims are being treated by the current US administration," Robert Boyd, a professor of nonlinear optics from the University of Ottawa told Nature Photonics. "From a broader perspective, I feel that the US may lose its pre-eminence as a host for scientific meetings [...] other places such as Canada might be a preferred place to hold international meetings."

During the order's implementation, the lack of warning to airport authorities and staff fuelled confusion, in particular, with

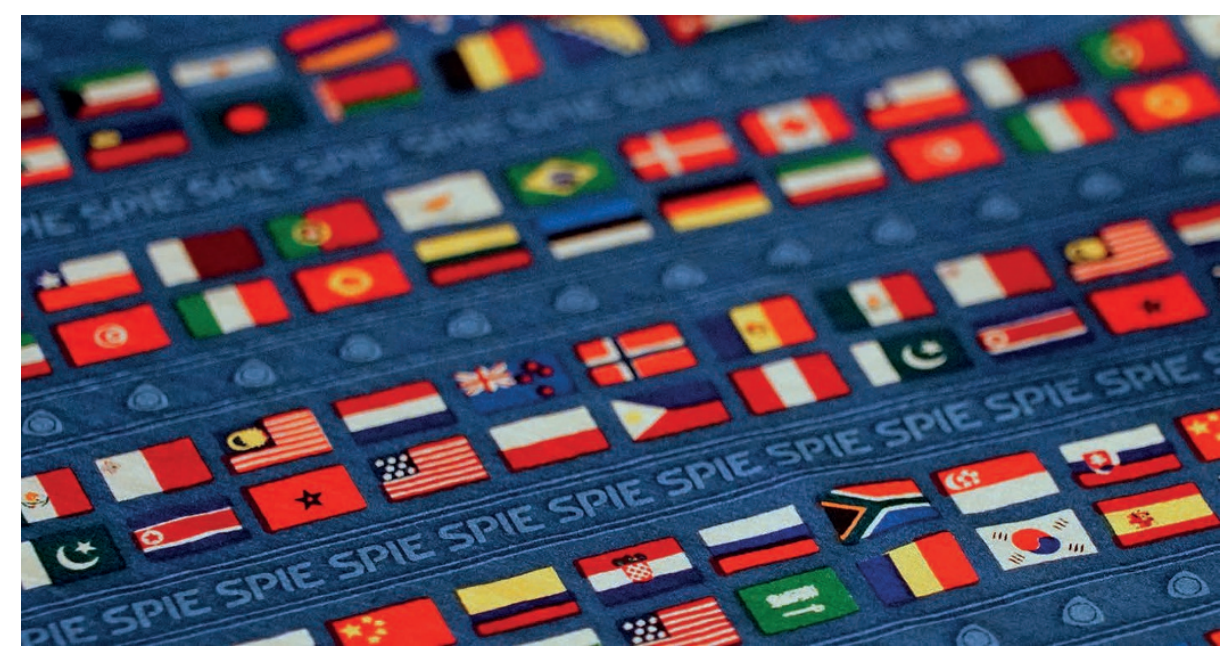

respect to travellers from the listed countries who held valid visas. Sahar Mirzaei, originally from Iran and now studying at the University of Southampton, UK, was due to fly from London's Heathrow airport to Photonics West with British Airways on the same day the order came into effect. At check-in she was assured there would be no problems since she had a visa.

"When the time for boarding came, as soon as the lady saw my passport, she handed it to an American gentleman, who tore up my boarding pass - without explaining the situation first - and let me know I was not able to get on the plane," Mirzaei explained to Nature Photonics. "British Airways would not refund my ticket, and I lost some money on my hotel booking too. That's a shame as I was preparing for months for the conference and the visa."

A day after the executive order, the photoacoustics microscopy researcher Parsin Hajireza (a permanent Canadian resident based at the University of Alberta holding a United States visa), arrived at check-in early for his trip to Photonics West, anticipating additional delays in passing through security. At this stage, however, the situation was becoming clearer worldwide; Hejireza was not issued a boarding pass.

"Honestly, it was a very humiliating experience, no one deserves to get judged or discriminated based on things they have not chosen in life," Hajireza told
Nature Photonics. "People must be judged (if they have to) based on their capabilities, their choices and who they are right now [...] I think sometimes people forget the fact that we are all human beings. Nothing is more dangerous than hate for our world right now."

The travel restrictions affected not only people travelling to the United States, but also those from listed countries currently based in the United States on valid visas wishing to travel abroad (and return to the United States).

The executive order was intended to last 90 days (for travellers, 120 days for refugees), but the United States courts halted it long before that. Mirzaei says she is unlikely to travel to the United States anytime soon, as she feels unwelcome. Hajireza is disinclined to travel to the United States "for the next four to eight years" for vacation or personal matters. However, when it comes to contributing to science, he doesn't want to miss out and would attend conferences or professional events in the United States, if able.

At the time of writing, a new travel ban has just been announced, which is due to take effect on 16 March 2017. In the new version, Iraq has been removed from the list of countries, and it appears that those with valid visas will be exempt, but of course, we encourage readers to check with up-to-date sources before making travel plans. 